\title{
Karl Polanyi and substantivism in economic development
}

\author{
Karl Polanyi e o substantivismo \\ no desenvolvimento econômico
}

\author{
WALDECY RODRIGUES*,*** \\ NAYARA SILVA DOS SANTOS ${ }^{+,+}$
}

\begin{abstract}
RESUMO: Uma leitura da obra de Karl Polanyi possibilita uma visão mais ampla e plural do processo de desenvolvimento, para além da dimensão exclusivamente econômica. Este artigo tem como objetivo resgatar o aporte teórico de Karl Polanyi e sua contribuição para o entendimento do processo de desenvolvimento a partir de uma concepção plural e substantiva da economia. Uma lição fundamental aprendida nesta pesquisa é que independentemente do sistema econômico de um país se deve atentar para a variedade institucional existente e a complexidade de seu mosaico cultural e social. O verdadeiro desenvolvimento só será conquistado se for estruturado com políticas públicas eficazes em promover esta heterogeneidade ao máximo bem-estar social possível.
\end{abstract}

PALAVRAS-CHAVE: Desenvolvimento econômico; Karl Polanyi; economia plural.

ABSTRACT: A reading of Karl Polanyi's work gives us a broader and more plural view of the development process beyond the exclusively economic dimension. This scientific text aims to recover the theoretical contribution of Karl Polanyi and its contribution to the understanding of the development process from a plural and substantive conception of economy. The key lesson learned in this research is that regardless of a country's economic system, one should pay attention to the existing institutional variety and complexity of its cultural and social mosaic. True development will only be achieved if it is structured with effective public policies in order to promote this heterogeneity to the maximum possible social welfare.

KEYWORDS: Economic development; Karl Polanyi; plural economy.

JEL Classification: B59.

\footnotetext{
* Professor do Programa de Pós-Graduação de Desenvolvimento Regional da Universidade Federal do Tocantins - UFT, Palmas/TO, Brasil. E-mail: waldecy@uft.edu.br. Orcid: https://orcid.org/0000-00025584-6586.

** Waldecy Rodrigues thanks the support from Federal University of Tocantins.

+ Doutoranda do Programa de Pós-Graduação de Desenvolvimento Regional da Universidade Federal do Tocantins - UFT, Palmas/TO, Brasil. E-mail: nayarasantos@uft.edu.br. Orcid: https://orcid.org/00000002-9819-4223

${ }^{++}$Nayara Santos thanks the support from Capes. Submitted: 21/November/2016; Approved: 25/March/2019.
} 


\section{INTRODUCTION}

Karl Polanyi (1886-1964) is considered one of the most prominent social scientists of the twentieth century. However, we believe that in contemporary economic and social thought, his contributions are not yet considered in the greatness merited by the importance of their theoretical statutes. His work is a percussion of interdisciplinarity in the social sciences. When almost nothing was said about it, Polanyi had already crossed the rigid frontiers of knowledge and transited through economics, history, anthropology and sociology. Throughout his main analyses, he sought to understand the general features of capitalist society in the context of a comparative theory of economic systems and institutional changes.

For a long time, the theme of economic development has been fundamentally associated with force expansion of production and its results in terms of technical progress and the growth of wealth. The limitations of the concept naturally announced the need for a broader and deeper reading of a process that, in its nature, is already multidimensional. Karl Polanyi, in overcoming this economic vision, inserts propositions that point to development with a more integral conception, valuing new articulations between the state and civil society while involving cultural, social and environmental aspects.

Karl Polanyi specifically made a major contribution to economic science not only because he was one of the best economic historians ever, but most of all through his "discovering" the importance of considering economic thought in its substantive sense. The validity of the formalist scheme in economic science, advocated mainly by the so-called neoclassical mainstream according to Polanyi, is limited to the analysis of market economies in which price-creating markets play a central role, and the only important institutions are those for rationality instrumental of utilitarian maximization. However, following the Polanyian logic, one should not automatically and uncritically project the solutions of "market" in the other spheres of social life since simple transport would not be effective due to how these questions are not adequately understood through the same rationality.

After showing the limits of the definition in the formal sense of economics, Polanyi emphasizes the feeling noun that reveals man's interaction with his natural and social means in order to produce the goods he needs to live. Understood as such, the economic activity inherent to all societies can take on many forms while not obeying a single rationality, nor arising from scarcity (Benjamim, 2012). The economy in its substantive sense refers to an entire area of social life in general, completely circumscribed by practices, rules and institutions, whose objective is the production, distribution and consumption of resources, goods or services necessary for the individual and the collective (Sobel, PosTEL, 2016). Substantial economics is the system of institutions, values, and practices that a society uses to define, mobilize, distribute, and organize capabilities and resources to best meet the legitimate needs of all according to Coraggio (2014). Such rationale was inspired by Polanyi's thinking and continued by its followers.

According to Machado (2010), all of Karl Polanyi's analyses of the distinction between the concept of economy and the formal and substantive sense of the concept is to show that economics is not a disengaged and autonomous sphere in rela- 
tion to society being that it is embedded in social relations. The importance of the concept, (dis) embeddedness, is closely associated with Polanyi's comparative analysis between the market economy and the economies of the past. According to Polanyi, the "embedded" or "descaled" character of an economy depends closely on the presence (or absence) of a system of price-making markets and whether or not a market economy is central to thinking.

The idea of the (dis) embeddedness concept gained prominence in the Social Sciences, especially in the so-called area of Economic Sociology. The term has become a key conceptual tool to explain the social and psychosocial characteristics of human behavior that are marginalized by orthodox economic analysis (DALE, 2011). Nevertheless, there was a historical distance between the meaning used by Polanyi and the concept spread over the last decades. The conceptual dissimilarities, according to Dale (2011), occur for lack of awareness of the sources on which Polanyi built the concept.

This article, therefore, aims to retrieve the theoretical contribution of Karl Polanyi, whose meanings and importance continue to be the subject of debates in several fields of knowledge, for a broader and more plural understanding of the economic development process. This, in turn, will allow for analytical inclusion of a contemporary agenda of development regarding social, cultural and environmental aspects.

\section{THE RECONSTRUCTION OF ECONOMIC THINKING ABOUT KARL POLANYI}

This section intends to analyze Karl Polanyi's seminal ideas on how the idea of plural economics can be associated with an understanding of the development processes of countries and regions. The Polanyian view leads to a reading that development is best understood in all its breadth and complexity when its foundational relations are considered with the webs of social life.

Thus, 'culture, environment, indigenous peoples and civil society' matter. That is, these are aspects that produce essential elements for any economic or social policy strategy that seeks to achieve a consistent and equitable process of integral development for its populations, especially for the varied structures of capitalism in the world. Without these strategic concerns, concrete development actions can produce an inverse effect on their objectives, generating many side effects such as the so-called negative externalities.

Undoubtedly, Karl Polanyi's best-known work is the "Great Transformation." Originally published in 1944, it is a profound book in which theoretical dialogue is combined with historical and anthropological digressions on the evolution of primitive modern market economies. This work continues to inspire critical reflection about the permanent pursuit of societies for their development, mainly because of the reductionist and presumptuous character of liberal thought, which, by applying its economic precepts arbitrarily in the various areas of a country without considering its specificities, can be deleterious and sometimes irreversible. 
The 'Great Transformation' is largely a book on the dynamics and consequences of the Industrial Revolution. Polanyi reports how this process transformed the entire social context making the market become an autonomous institution, virtually free of the control of social institutions. This process generated a historical alternation between the social control of the economy and the control of markets over society.

If in a phase prior to the Industrial Revolution a society was experienced and in such a society economic activity was exercised as one of the many procedures of human activity, and therefore, the economy served human needs, over time it was fed the idea that markets would regulate themselves if laws and regulations allowed for it. With the Industrial Revolution, the economy was in a place of primacy with respect to the social regard of life. The market, which as a rule was immersed into the society that regulated it, became the regulator of society (Polanyi, 2012a).

This alternation placed all spheres of human life and subdued the law of supply and demand. Basic elements such as land (nature), labor (the very usefulness of human life), and money, have become "fictitious commodities" and have come to be defined by commodity exchange patterns. The commodification of these elements (land, labor and money) has concretized a market society, a society in which the market is a regulating element and all other spheres of social life are denied. "Mercantile fiction put man and nature into the hands of an automaton (a mill), operating in its own circuits and being ruled by its own laws" (Polanyi, 2012b, p. 53).

Modern economies, according to Polanyi (2012a), are political constructs. Polanyi was categorical in expressing that modern commercial society arose from a conscious imposition of the most powerful classes with fundamental subsidy of the state. The autonomy of the capitalist market was not an evolutionary process with regard to social dimension, but rather a political imposition sponsored by the liberal state. The adherents of the liberal ideology articulated the system in order to validate policies and measures that contributed to self-regulation of the market, in turn creating the conditions to make the market the only organizing power in the economic and social sphere.

Society then came to be interpreted as a market society and man as a purely economic being. Polanyi finds this fact unnatural, for human institutions detest pure motivations; "Just as the sustenance of the individual and the family is not usually dependent on the hunger motivation, the institution of the family is not based on sexual motivation. Man is not a purely economic being, and society is not a market society" (Polanyi, 1947, p.13).

Polanyi, as an economic historian, has shown that the Industrial Revolution has brought forth a new world erected under the 'shards of the old one.' The world before the Industrial Revolution, in full operation, was governed and ruled by specific customs, supported by patterns in which social relations were woven in a particular way. The so-called 'Satanic Mill' of the great transformation made this entire structure crumble. The intuitions and basic pillars of this world gave way to new ones, which to society was only the painful process of adjusting to these new structures.

In the new world a different set of rules and arrangements were developed to align human subsistence and social existence with market imperatives. The relations of markets were extended, becoming denser and more diffused, while the relations of life itself, in community and in family were subordinated to the logic of the mar- 
ket, passing the market economy to assume a life of its own and dominate social life (Stiglitz, 2012).

The main difference was the place occupied by the economy, or rather embeddedness in social relations, and was now descaled. The social consequence of this complete freedom is the removal of the human side from the economic aspects of life (Wjuniski, Fernandez, 2010). In this world, man has become a purely economic being and the human economy has become a market economy.

In about a hundred years, all of Europe formerly made up of sites, tenants and artisans became a Europe of industrial cities. The capitalist market system restructured the economy as a self-governing and independent sphere with its own logic and laws of motion, dismembering it from society by creating markets for land, labor, and money (Foster, 2016). Rapid transformations, however, at the same time as they created a new set of rules and requirements, destroyed mechanisms of coverage and previous safety nets before it was possible to devise new mechanisms of coverage (Stiglitz, 2012).

Polanyi (2012a) has shown that the expansion of market relations in the period of the Industrial Revolution has severely shaken the web of solidarity and familiarity, causing a real erosion of social relations in English society. Stiglitz (1980) shows that this process was not unique to nineteenth-century England. Countries such as Russia and Indonesia underwent similar processes. The manner and pace of the reforms implemented in Russia have caused the erosion of social relations, destroyed social capital and led to the emergence of Russian mafias. Similarly, the elimination of food subsidies in Indonesia, at a time when wages were falling sharply and unemployment rates were rising, led to political and social chaos.

For Polanyi (2012a), the increase in poverty was mainly due to the new configuration of the rural environment, where there was a change in the pattern of land use and ownership, contributing to the weakening of social ties in the countryside. The increase in agricultural productivity, fundamental to the strengthening of the market economy, uprooted the worker and virtually destroyed the social security of rural workers. Their survival, which was once assured by a hybrid system of production and distribution in which social ties were central to determining their standard of living, became almost entirely dependent on market relations.

The transformation narrated by Polanyi not only destroyed the mechanisms of cover, but also destroyed the whole social context of an era. The historical proof of the illusory character of a market society was its collapse in the 1930s. This is a cyclical process of the 'pendular' type, which seems to repeat on a regular basis insofar as the institutions that support the quest for how the well-being are eroded by the forces sustained by the prevailing economic interests.

For this reason, it is important, even in a capitalist economy that wishes to be 'healthy' and not only tied to economic interests, that sometimes it only deteriorate its living conditions. It is important to realize that there is an important institutional variety that can restore important social forces that can lead a country or region to achieve better levels of development.

The origins of all devastation lay in the utopian effort of a self-regulated market system and in promoting the emancipation of markets of social control. According to Polanyi (2012a), markets and the economy should be an accessory to social rela- 
tions, a means of helping the exchange of goods and services, but should never replace social relations, as they did during the industrial revolution and beyond that point. The completely free market transforms all of the characteristics of social life into marketable goods, as happened with land, labor and money (Wjuniski, Fernandez, 2010).

For example, the earth, as part of the planet, was not produced by humans, let alone was it for sale. The workforce is just another name to refer to humans, and money is not merchandise (Maya Ambia, 2014). According to Polanyi (2012), money is a political creation. It is a sign of value and a means of exchange. Thus, it is not something that is produced to be sold in the market. The prices charged for these goods are, respectively, rent, salary and interest.

Polanyi has always sought to understand the possibility of establishing an economy in the service of another type of social contract. For this reason, he sought references in other economies in the history of pre-capitalist peoples and civilizations. In these societies, he realized that the known economic systems were organized according to the principles of redistribution, reciprocity, domesticity, exchange (market) or by some combination thereof. Each of the principles associated with an institutional support model can be "identified in any society as factors of organization of the production and distribution of wealth" (Pinto, 2006, p. 46). Principles are actually forms of integration that designate institutionalized movements by which the components of the economic process are connected.

The need to move beyond the uprooted economy should not be understood as a return to a rooted economy. In general, Polanyi $(2012 b, p .223)$ argues that the solution lies in the "restoration of the unity of motivations that must guide man in his daily activity as a producer and in the reabsorption of the economic system in society and the creative adaptation of our living in an industrial environment." In Polanyi's narrative (2012a, 2012b), the role that the state as a dimension played in the transformation is a manifest. In eighteenth-century England, the state was the great articulator for the establishment of a self-regulating market and the party was responsible for the great transformation undergone by English society.

At the height of the Industrial Revolution, the state acted simultaneously as an agent of transformation and social deregulation. Multi-secular traditions and customs of peasants from all parts of England, craftsmen located in the incipient cities and immigrants from various other regions of Britain were drastically transformed or destroyed, becoming, at best, fashions. Economic history shows that the emergence of national markets was by no means the result of the gradual and spontaneous emancipation of the economic sphere from social control. On the contrary, the liberation of markets was the consequence of a conscious and sometimes violent intervention by the government that imposed on society the organization of the market (Rodrigues, SantOS, 2017).

Economic history also shows that the liberation of the market from social control was not the result of a gradual and spontaneous emancipation. The capitalist way of institutionalizing the economy during the nineteenth century was actually the result of its own construction and politics. The autonomous market is the result of the conscious action and articulation of the state in favor of a transformation of history that has debased multi-secular traditions and customs. This created 
a situation that led to unsustainable situations which generated new actions of politics in a double movement that Polanyi interprets not as a mechanical movement, but as directed with the intention of overcoming the tendencies for the self-destruction of society (Coraggio, 2014). Polanyi's argument was that the cataclysmic events of the time such as World War I, the rise of fascism, the Great Depression, the implosion of the world market, and an arms race that pointed to a new global conflict were not isolated facts but manifestations of a problem underlying the rupture of social unity, which was rooted in the "market society" (Dale, 2010).

In the vain attempt to legitimize deregulated action, some authors of economic history argued that by measures of income levels and population growth, the conditions of English workers were better in the new industrial context than in the previous rural society. Polanyi refutes this idea by stating that "in reality, a social calamity is basically a cultural rather than economic phenomenon that can be measured by income or population growth." Although real money income has grown for many individual workers, material insecurity has also increased because of the threat of industrial unemployment and the disappearance of livelihood guarantees sustenance for the unfortunate. Both of these aspects characterize rural societies in which kinship and neighborhoods remain in place (Nunes, Schwartzman, WroBEL, 1977).

The English laws of the time make evident the political intervention of the state in a way that is in favor of the transformation of the market society. The Law of Enclosures gave the nobles the legal right to expulse peasants from the land; the Law of the Poor of 1834 restricted social assistance; the Wheat Act in 1846 prohibited the importation of foreign wheat and acted for the benefit of large landlords. All of these impositions show that the state was side by side with the development of self-regulated markets. The modern state was so strong as to create conditions conducive to the market system, thus pressuring changes in the social structure. At the same time, this economy required a strong reaction from society to mitigate its transformative effects. This process was called "double movement" by Polanyi because one force is seen as a reaction to the other: the evolution of the markets and the development of the liberal creed forced society to protect itself (Wjuniski, Fernandez, 2010).

In the current context, Polanyi's thinking allows the legitimization of the state's regulatory action in the economy as a way of defending society against the processes of globalization, commodification, labor and fiscal deregulation, consequently serving hegemonic interests. At this point, Polanyi's legacy is very much read with a tradition that, in general terms, can be linked to the work of John Keynes (1936), a conscious advocate of the interventionist state economic policy (Curto et al., 2012).

Polanyi was not necessarily a theorist aprioristically against the 'market'. From the author's point of view, markets are important institutions; complex society could not exist without them. The criticisms made by Polanyi are directed at the selfregulating market system - a market economy operating only according to the law of supply and demand. For Rodrigues and Santos (2017), markets have always been present in the social context and this is a fundamental element necessary in order for societies to evolve. The central problem is that when the market becomes selfregulating and the structure of the state simply obeys, it dictates even going against the general well-being of its population. 
Polanyi argues that the problems of the economy have a social, rather than a political root. Therefore, the power of the state, by itself, could not solve them. Such problems would have to be solved through a social and cultural transformation. Polanyi is categorical in saying that in earlier societies, as a rule, an individual had only his or her own subsistence threatened if the whole community was also in a similar situation. In contrast, modern society, which was born through the Industrial Revolution, created a system that "blackmailed" the very subsistence of humanity. In this system, the human need became ancillary to the market. "The nineteenthcentury society organized itself in a way that made only hunger and profit an effective motivation for the individual to participate in economic life" (Polanyi, 2012b, p.55). The construction of markets made human subsistence cease to be the major motivation for production. There was then a "reversal in the motivation of actions by members of society: profit motivation replaced subsistence motivation" (Polanyi, 2012a, p. 44).

On the other hand, Polanyi was a great admirer of Robert Owen's communitarian cooperativism and the idea of a community-based social organization in education and class co-operation. According to the author "only Owen discerned the emerging reality behind the veil of the market economy: society. His vision, however, was lost again for a century" (Polanyi, 2012a, p. 92). Robert Owen sought to create alternatives to the market's weaknesses, seeking to restore the bonds of solidarity that had been broken through cooperatives, associations so that people would not be completely subject to the market.

Next to the phenomenon of cooperativism, there are currently the experiences of social and solidarity economy. These forms of economic organization are seen as one of the ways to fill the gaps left by the crisis of solidarity, while at the same time they have production alternatives that redefine the economy beyond the market. The social and solidarity economy is based on the hybridization of resources and the strengthening of interpersonal social bonds in local organizations. It would be like a kind of Polanyian reconstruction of ties that are fundamental to survival and wellbeing. They cannot be seen as a panacea, but rather they can be extremely useful in the search for models of development that have the human being as the focal point.

Are forms of cooperativism, social and solidarity economy possible in the market economy? More than being merely possible, they are in fact extremely useful. As a rule, the market system is unable to promote an adequate generation of decent work opportunities in an expanded way within the economy. As part of a productive system the social and solidarity economy can represent forms of complementarity to the markets, resulting from collective actions that would be able to generate job opportunities that would not be generated only in the marketing conception. The social and solidarity economy can reestablish the bases of sociability and activity that nourish interpersonal relations in society to the detriment of the extension of only the mercantile relations (Francia Filho, Laville, 2004; CoragiO, 2014).

The coexistence of these principles and patterns in previous societies, according to Polanyi (2012a, 2012b), show that the economy has always allowed a plurality of forms. The current discussion of plural economics is in terms of revising the usual assumptions of the character and nature of economic activity, particularly the one 
that reduces it to the idea of the market principle. Principles can be viewed as important dimensions in rebuilding a non-market-centered, pluralistic economy.

\section{KARL POLANYI AND PERSPECTIVES FOR A PLURAL ECONOMY}

A first, and perhaps central, thought-of reflection is how development strategies are succeeded. Even in the varieties of existing forms of capitalism, this must be complex and plural. It is necessary that it be complex because it must be understood that it is the international markets that determine the possibilities of actions of countries, but that these actions depend on the level of strategic intelligence and recognition by these governments. The development process to be achieved should exploit the existing competitive advantages as best as possible while still considering that there are specificities in 'social and environmental assets' that, if disregarded, make the insertion of their countries peripheral and harmful in several aspects. On the other hand, the search for development must also be plural. That is, in order to recognize that economic growth in the capitalist system is insufficient in generating job opportunities in quantity and quality so that forms of plural economy such as cooperativism, solidarity economy and collaborative economy must be strongly stimulated.

Polanyi offers a compelling critique of the self-regulating market by focusing on the artificial nature of an economy that does not place the needs of society at its center. Much of Polanyi's work is devoted to studying and theorizing the specific ways in which early societies sought to develop institutions that could embed the economy in social relations, thus avoiding the emergence of an autonomous market. Economic history and the study of societies of the past are important tools for understanding our economy and our times. Comparisons can offer insight and validate key considerations. Among the similarities present are the constant tensions between market, state and society.

In the era of neoliberalism, the concept of the "double movement" of Polanyi's thesis returns to the forefront, mainly due to the current financial crises which signal a pendular movement. Dale (2012), in analyzing the return of this movement, reflects on whether or not neoliberalism arose as a result of a process of oscillation. He arrives at the following question: what is to be expected from the next movement? The imprecision that remains is the direction that the current system moves towards a form of socially coordinated capitalism, or towards "more of the same." Fraser (2014) and Maya Ambia (2014) show the fact that transforming the foundations of social life into fictitious commodities has a strong echo in 21 st century society. According to the authors, it is possible to see what the commodification of the land, the labor force and money represent in contemporary society. Some of the effects were widely announced by Polanyi while others were not noticeable at that time.

In a very incisive way, Fraser (2014) states that the crisis that has arisen today encompasses not only economics and finance, but also ecology, society and politics. The ecological side of the crisis is seen in the depletion of the Earth's nonrenewable resources and, with severe effects on the world such as global warming. The finan- 
cial slope of the crisis is reflected in the creation of a parallel economy of paper values insubstantial, but is also capable of devastating the real economy. The social reproduction aspect is reflected in the growing difficulty in the human capacities available to create and maintain social ties, which includes the work of socializing youth, building communities, reproducing shared meanings, having affective dispositions and valuing horizons that underpin social cooperation.

The commodification of the land has provoked its own speculation, such as the stripping of land, of peasants or, in the case of some Latin American countries, indigenous communities and riverine communities. It has also provoked speculation with prices of urban land that led to serious housing problems, rising cost of living in large cities and fraud by real estate companies. The other visible problem, although Polanyi did not develop its criticisms in this direction, are the environmental destruction effects. All environmental damage caused by the treatment of land, water, subsoil, air, climate change was considered as if they were subject to the dictates of supply and demand. Additionally, because they are not commodities, it is impossible to measure their true value with money (Maya Ambia, 2014).

The issue of climate change is an emblematic example. The impacts of various economic activities on the environment are often neglected or even doubted despite strong scientific evidence of such hazards. Several countries, especially when led by highly pro-market governments, are reluctant to participate in international efforts to reduce this environmental risk, claiming they lack sufficient evidence and that such efforts are damaging their economies.

The commodification of the labor force beyond the phenomenon of unemployment already announced by Polanyi and lived in the origin of capitalism is made invisible in the eyes of the market and the unemployment of women leaves them to do work inside of their homes. Work is indispensable for the training of citizens, but because it has no value, it forces women to sell their work force as if it were a commodity. In doing so, they leave their families or at least spend less time with them. In developed countries, mothers work as salaried employees in order for their jobs to be performed by other women who are usually immigrants from underdeveloped countries. This happens as a chain reaction that affects society as a whole.

Another relevant variant warned by Maya Ambia (2014) is child labor, which constitutes a social calamity in the current context. The consequences of this commodification are even more serious as it affects not only the present life, but the future of these children as well, which is placed in the hands of the blind forces of the market. The consequences of the commodification of money in our time have already multiplied the evidence pointed out by Polanyi and the financial and monetary crises have been repeated. Yet the author envisages an emerging reality, which is the set of new phenomena not addressed by Polanyi: the ecological crisis, the presence of women in the economy and the increase of inequalities in multiple spheres.

Coraggio (2014) shows that in the peripheries of the world system, despite all of the processes of destruction through despotic colonialism and commodification, there is a structural heterogeneity with respect to the institutional forms and corroborating with the recovery of the Polanyian principles of production and distribution. In these peripheries, as the process of industrialization, individualization and development of conditions for the functioning of the markets has not been fully 
concluded. There are still sectors that are not monetized, important parts of nature and work that have not been commodified and well considered public policies can be an alternative to the implementation of plural economy strategies, such as ecologically relevant regions that need to develop their economies in other bases or that are at risk of extinction.

Regarding Latin America, as a specific part of the periphery of the capitalist world system, Coraggio (2014) attests that Latin American economies are not pure market economies and likewise, neither are their societies complete market societies. He classifies them as mixed economies under capitalist hegemony formed by three sectors: the entrepreneurial capital economy, oriented to the private accumulation of capital; the popular economy, oriented to the reproduction of the life of domestic units, including everything from subsistence activity to segments highly linked to business economy; and the public economy, oriented to a combination of systemic needs, the common good combined with capital-dependent governance, the accumulation of particular power, and the strategic legitimization of the system.

Reflecting on a development model based on Polanyi and capable of answering questions of the first order which still persist in the literature is a necessary challenge. Polanyi shows that it is possible to reconstruct and rethink a model that is not just market-centered. One valuable lesson from Polanyi that can serve as a guide is that economic problems must be solved through social and cultural transformation. The construction of an economic system in which structural heterogeneity persists is affirmed with political action in the direction of an economy distinct from a market economy (Coraggio, 2012).

For Wjuniski and Fernandez (2010), much of Polanyi's effort, in the whole of his work, was to show that the market itself is not a sufficient mechanism to organize the economy in order to ensure social cohesion. Emphasizing the need for states and society to develop other mechanisms in order to prevent imbalances generated by the market. The authors reaffirm that in these days of globalization and neoliberalism, these concerns raised by Polanyi must constantly be on the agenda so that the problems of human subsistence can be better treated.

An accepted understanding today is that development is a process beyond the domain of the economy identified by economic progress. It is a process in which a set of social, cultural, political-institutional, economic and environmental factors interact among themselves revealing a multidimensional phenomenon in its causes and its results. Polanyi's theory recognizes economic activity as socially and historically characterized and localized. In this sense, the author talks about the social organization of the economy as an instituted process. The author used the word instituted because it is defined by the empirically constructed interaction between man and his environment, resulting in the satisfaction of both his material and psychological needs.

Finally, it was verified that the richness of the reading of the work of Karl Polanyi really gave rise to new light for the construction of the development policies for the countries and regions, mainly in what would be the best form of government action in the economy. The reflection on the works of Polanyi draws attention to the following fundamental points: 1) capitalist growth as a rule is insufficient for the production of jobs in scale and quality adequate to meet the needs of the 
population; 2) for the promotion of development, it is fundamental that social, environmental and cultural issues come to the center of the agenda of governmental action, not in its periphery, as is usually done when economic elites have a narrow view of maximizing their profits without due social responsibility; 3) it is fundamental that alternative forms of economic organization be disseminated into society, such as: cooperativism, solidarity economy and collaborative economy; so that there is a greater capacity to generate self-employment in society, without depending exclusively on the pendulum movements of private investments, especially the international ones that are subject to specific conditions of risk and return, sometimes optimized by reducing the cost of labor and the easing of environmental, labor and social security laws, which sometimes becomes more of a burden on society than a good alternative.

\section{FINAL CONSIDERATIONS}

Karl Polanyi's conclusions on the economic trajectory of the countries in the Industrial Revolution, the way in which the market economy became market society, and how this entire process virtually smashed the previous ways of life and affected the social protection systems are arguments with a great interpretative power in the present times of the 21st century. The current challenges are other such arguments with a larger dimension, such as global warming. However, the central problem remains the same: when it comes to accumulating wealth and generating business opportunities, there seems to be no limits for economic agents, and the governments and the political and institutional representations are, in most cases, simple games of this infamous gear, which Polanyi wisely called the 'Satanic Mill'.

Polanyi has put forward some hypotheses that may be useful for formulating new policies for more equitable and balanced development, based on the principles of redistribution, reciprocity, domesticity and market. There is some misunderstanding that the defenders of the Polanyian ideals for the constitution of the theoretical edifice of development are a kind of 'utopian socialists' of the twenty-first century, which constituted a shallow critique and devoid of more in-depth foundations.

It is known that the development process in any economy is objectively given by the transnational economic and political circumstances and the national structural conditions. But national institutions will be somewhat more effective in pursuing development as long as they establish economic and social policies that take into account the specificities of the social and environmental 'assets' involved. In this sense, supporting the various existing forms of plural economy in addition to defending the disadvantaged from the standpoint of the natural process of capitalist accumulation, contributed greatly to building a healthier economy and society. It can be concluded that one cannot confuse utopia with lack of imagination on the part of those who blindly defend liberalism.

After a century of blind "development," Polanyi hoped that man would be able to restore his habitat. His hope was that modern society would be able to build a new world with solid structures, balancing the forces that drive society towards 
progress. The desire of Polanyi's work is to show the need for social reconstruction through other forces that can move the system towards an equilibrium. If indeed he shows the answers that are unknown, then there are at the very least clues available which feed the prospect that it is possible to cast a new look under the development process.

Even for capitalist systems, a lesson learned from Karl Polanyi is that one must pay attention to the institutional variety existing in a country and / or region. Additionally, there are several issues that must be dealt with in a specific way if the central objective is to obtain the levels of development possible in a given historical time. For example, the environmental issue in all its complexity, the best use of biodiversity, the issue of indigenous and traditional peoples (indigenous, Maroon people) are issues that cannot be addressed by a simple free market rationality since this is not enough, and sometimes not necessary, in the search for the best possible solutions for them. It is necessary to think outside of the box and understand that, as a rule, a country is a true cultural and institutional mosaic. The key is to know that true development is structured with public policies that are effective in promoting this heterogeneity with the maximum well-being.

In more pragmatic terms, this article concludes that a closer reading of Karl Polanyi's work does indeed provide new perspectives for the construction of development policies for countries and regions, especially in what would be the best way for a government to act in the economy and society in order to achieve these goals. With this, it is possible to think of strategies and policies capable of bringing to the countries and their regions a development process that generates new opportunities for work, does not reproduce social problems but preserves the right to a healthy environment for present and future generations. To this end, it is fundamental that institutions be articulated in this direction, considering that in order to have integral and sustainable development, the economy must function on a more plural basis.

\section{REFERENCES}

ARAÚJO, P. H. F. (2015) “Polanyi e Granovetter a partir do olhar de Lukács”. Revista Econômica, v.17, n.1, p. 113-131, junho.

BECKERT J. (2009) “The social order of markets". Theory and Society. Volume 38, Issue 3, pp 245269.

BENJAMIM, C. (2012) "Notas da edição brasileira". In: K. Polanyi, A Subsistência do Homem e Ensaios Correlatos. Organização Karl Polanyi Levitt. Rio de Janeiro, Contraponto, (1 ${ }^{\mathrm{a}}$. ed. inglês: 2012), p. 11-44.

CANGIANI, M. (2009) "Karl Polanyi: une voix du siècle passé”. Revue du MAUSS, Issue 3, pp 336348.

CANGIANI, M. (2012) "A teoria institucional de Karl Polanyi: a sociedade de mercado e sua economia ‘desenraizada'”. In. POLANYI, Karl. A Subsistência do Homem e Ensaios Correlatos. Rio de Janeiro: Contraponto.

CORAGGIO, J. L. (2012) "Karl Polanyi y la otra economía en América Latina”. In: Universidad Nacional de General Sarmiento (UNGS) / Consejo Latinoamericano de Ciencias Sociales (CLACSO). Karl Polanyi: Textos escogidos. Buenos Aires: UNGS/CLACSO.

CORAGgIO, J. L. (2014) "Una lectura de Polanyi desde la economía social y solidaria en América Latina”. Cad. Metrop., São Paulo, v. 16, n. 31, pp. 17-35. 
CURTO, D. R; DOMINGOS, N; JERÓNIMO, M. B. (2012). “A “Grande Transformação”, de Karl Polanyi: questões de interpretação.” In Polanyi, K. (Eds.). A Grande Transformação: As Origens Políticas e Económicas do Nosso Tempo (pp. 9-37). Lisboa: Edições 70.

DALE, G. (2011) "Lineages of embeddedness: on the antecedents and successors of a polanyian". American Journal of Economics and Sociology, Vol. 70, No. 2 (April).

DALE, G. (2012) "Double movements and pendular forces: Polanyian perspectives on the neoliberal age". Current Sociology, vol.60 edição 1, pp.3-27.

FRANÇA FILHO, G. C; LAVILLE, J. L. Economia Solidária: uma abordagem internacional. Porto Alegre: UFRGS.

MAYA AMBIA, C. J. (2014) “Actualidad de la crítica de Karl Polanyi a la sociedad de mercados”. Polít. cult. [online], n.41, pp.143-166.

MACHADO, N. M. C. (2010) "Karl Polanyi e a nova sociologia econômica: notas sobre o conceito de (dis)embeddedness. Revista Crítica de Ciências Sociais, 90, Setembro: 71-94.

FRASER, N. (2014) "Can society be commodities all the way down? Post Polanyian reflections on capitalist crisis." Economy and Society. Volume 43 Number 4 November: 541-558.

NUNES, M. B; SCHWARTZMAN, S; WROBEL, V. (1977) "Estratificação social e educação: caminhos e alternativas para o homem do campo". Revista de Ciências Sociais, vol. 16.

PINTO, J. R. L. (2006) Economia Solidária. De Volta a Arte da Associação. Porto Alegre; UFRGS.

POLANYI, Karl. (2012a) A Grande Transformação: As Origens de Nossa Época; tradução de Fanny Wrabel. - 2. ed.- Ria de Janeiro: Elsevier.

POLANYI, Karl. (1947) A Nossa Obsoleta Mentalidade Mercantil. Repr. in Primitive, Archaic and Modern Economies, essays of Sari Fokunapi, George Dalton ed., Nova Iorque. v. 3. Fevereiro, p. 109.117.

POLANYI, Karl. (2012b) A Subsistência Do Homem E Ensaios Correlatos. Organização Karl Polanyi Levitt. Rio de Janeiro: Contraponto.

RODRIGUES, W e SANTOS, N. S. (2017) "Karl Polanyi e o desenvolvimento econômico: um novo olhar sobre o regional / local?” Revista de Desenvolvimento Econômico - RDE - Ano XIX - V. 1 - N. 36 - Abril, p. 168 - 190.

STIGLITZ. J. (2012) "Prefácio". In Polanyi, K. (Eds.), A Grande Transformação: as origens políticas e económicas do nosso tempo .Lisboa: Edições 70, pp. 9-37.

SOBEL, R; POSTEL N. (2016) "Formal economy, substantive economy, and economism: A critical interpretation of Karl Polanyi’s Distinction”. Philosophy of the Social Sciences, Vol. 46(5), pp.473-497.

WJUNISKI, B. S.; FERNANDEZ, R. G .(2010) "Karl Polanyi, Athens and us: The contemporary significance of Polanyi's thought". Brazilian Journal of Political Economy, vol. 30, no 3 (119), pp. 420-437 July-September. 